Kong Ziwei

Sumy State Pedagogical University named after A. S. Makarenko, Sumy, Ukraine

\title{
MUSICAL THINKING AND COMPOSING TECHNIQUE IN TERMS OF COMPUTER TECHNOLOGY DEVELOPMENT
}

\section{Kong Zizeei. Musical Thinking and Composing Technique in Terms of Computer Technology Development}

Determining the place of music computer technology in modern history requires a thorough consideration of musical processes and factors of the first half of the XX century, as well as the study of relevant discoveries, concepts and experiments in terms of new music technologies. The purpose of the article is to identify the patterns of development of musical art in relation to modern social life, appeal and thorough study of music of different styles and eras in their systemacity. The methodological basis of the study are dialectical and systemic methodologies used in the field of cultural studies. General scientific and logical methods of analysis, synthesis, induction and deduction, historical and comparative research of the problem are used. The historical evolution of musical instruments is deeply connected with the creative processes that take place in the fields of composition, acting skills, musicology and education. This led to the search and improvement of musical language, enrichment of compositional methods, techniques and means of texture of musical works and, as a consequence, the birth of electronic instruments.

Keywords: musical thinking, compositional technique, computer technologies, musical art.

Кун Цзівей. Музичне мислення і композиторська техніка в аспекті розвитку комп'ютерних технологій

Означено, що визначення місця музичних комп'ютерних технологій у сучасній історії потребує грунтовного розгляду музичних процесів і факторів першої половини XX ст., а також дослідження відповідних відкриттів, концепції та експериментів в аспекті нових музичних технологій. Виявлено закономірності розвитку музичного мистецтва стосовно сучасного суспільного життя, звернення й вивчення музики різних стилів та епох у їх системності. Методологічну основу дослідження становлять діалектична i системна методології, що застосовуються у сфері культурологічних досліджень. Використано загальнонаукові та логічні методи аналізу, синтезу, індукції й дедукції, історичного і компаративістського дослідження проблеми. Стаття є спробою дослідити творчі композиційно-технологічні принципи, методи та концепції, характерні для сучасного музичного мистецтва, нові форми музичного вираження. Практичне значення полягає в можливості використання основних положень статті під час написання наукових праць на відповідну тематику, у процесі викладання фахових навчальних дисциплін. Висновано, що історична еволюція музичного інструментарію глибоко пов'язана 3 творчими процесами, які відбуваються у сфері композиції, виконавського мистецтва, музикознавства та освіти. Це зумовило пошук й удосконалення музичної мови, збагачення композиторських методів, прийомів і засобів фактури музичних творів i, як результат, народження електронного інструментарію.

Ключові слова: музичне мислення, композиторська техніка, комп'ютерні технологї, музичне мистеитво.

Relevance of the issue. The intensive development of computer technologies, their widespread use in various types of music, has put forward a number of problems that need to be understood and solved by modern musicology. The impetus for the emerging and development of technical music and its variety - electronic music - in the XX century consisted in two factors: a) The desire of composers to find new means of expression in the art of music, to a new musical language and, as a consequence new tools;

b) Rapid scientific and technological development in the field of electronics and later in information technologies.

A bright "burst" of interest among musicians (and listeners) to unusual sounds, to new timbres, as well as the desire to at least somehow facilitate the extremely difficult work of the composer and performer, plus the emergence to use new information technologies have determined the use of computers in music creating. The first computers were not designed for this; the designers had to work, but without the musicians they would not have achieved such results. Now, this technique is ready to completely turn musical thinking over. And 
in a very short period of time in the historical aspect, this technique has united more than one million people; the interest to its possibilities in the musical sphere has become truly enormous. The appeal to information technologies, musical acoustics in their actual connections with music poses many difficult problems to researchers. Undoubtedly, the most important of them is the problem of the ratio of artistic (musical) and natural-scientific thinking or the issue of the ratio of figurative emotional perception of music and accuracy, objectivity of methods of its cognition. However, objective criteria allow to obtain knowledge only about the external, material manifestations of art. For the representatives of the exact sciences will remain hidden (if not forever, then for a long time) the spiritual essence of art, a basis component of aesthetic knowledge of music. Anyway, information technologies, music acoustics do not offer researchers such opportunities. Thus, scientists face the relevant issue of creating a method of perception the spiritual essence of art. Drawing attention to it is one of the objectives of the actual article.

Analysis of recent researches and publications. This problem was studied mainly by foreign musicologists, including: P. Bulez (2004), I. Xenakis (2008), A. Mol (1975) and others. Among domestic researchers we should mention S. Lazarev (2011), who studied electronic music as a form of artistic creativity, L. Kyianovska (2005), who studied the sociocultural aspect of electronic music development in the 50-70s of the XX century etc.

The relationship issues between the musical art and modern technological means had been being discussed long before personal computers appeared (that is, until August, 1981). Thus, in the west the works of A. Mol and his colleagues stand out. The Soviet researcher R. Zaripov (1971) also worked extremely productively in this direction. Thus, the conditions were created for the music direction of computer science and acoustics to be able to find new qualities and enter the practice of music art to become computer music technologies (computer acoustics).

This is based, firstly, on the experience of creative - composing and performing activity, which gives meaning, aesthetic essence to the music, which is associated with new techniques (electronic, computer etc.), and actively affects the musical instruments. Secondly, these are theoretical and practical works in the field of electricity, electronics and informatics. They have provided the creation and development of special hardware, software, electronic musical instruments. Thirdly, it is a special knowledge in physical, musical acoustics, architectural acoustics, electroacoustics, psychophysiology of hearing. They are specific for the development of this direction. Included in the system of musical knowledge, computer technologies and acoustics can be applied in a vast variety of cases - in composing, performing music, in music pedagogy, in special music studies researches.

The objective of the article is to identify the patterns of musical art development in relation to modern social life, appeal and analysis of music of different styles and eras in their systemacity.

Presentation of basic material. Determining the place of music computer technologies in modern history requiresathorough consideration of musical processes and factors of the first half of the XX century, as well as the study of relevant discoveries, concepts and experiments in terms of new music technologies. Thus, perception of the development patterns of musical art from a scientific point of view and an adequate idea of modern social life requires appeal and thorough study of music of different styles and eras in their systemacity. The emergence in the same historical period (XX century - present time) of a large number of different, quite opposite styles, leads to certain complications during the orientation in modern music.

Thus, in general terms, modern musical directions can be divided into two main groups, respectively, taking into account the following features:

1) thematic music. In it, the presentation of the main musical idea is concentrated in the relevant centers-topics;

2) athematic music, in which the leading musical thought, respectively, is not concentrated in these centers-themes.

Consideration of creative compositional and technological principles, methods and concepts characteristic of modern musical art, made it possible to divide the latter into:

- neo-modal (modal) and extended-tonal music;

- atonal music;

- pointillist music;

- technical music (tape, electronic);

- timbre music and aleatorics;

- extremist music (Kohoutek, 1976). 
At the same time, historical development leads to changes not only in public life, but also in all artistic and cultural spheres, naturally and continuously influencing the art of music in particular. This manifestation is reflected in the constant enrichment, new organization and use of its components, including: harmony, melodics, form, structure, instrumentation, rhythm etc.

New forms of musical expression also acquire a new meaning. Nothing changes even the historical fact that the style of the previous musical era is mostly denied by the new era, at the same time, elements of style of earlier periods of musical development continue to be used, already at a higher level. Thus, the following segment of the evolutionary sequence can serve as proof: vocal polyphony - baroque monody polyphony of the prosperity of baroque art classical homophony - romanticism - neobaroque - neoclassicism.

A striking example of the above mentioned facts can be the statement of A. Schoenberg, who until recently was considered an opponent of all traditional musical views. The composer remarked:"Idonotliketobecalled arevolutionary. What I have done can be considered neither a revolution nor anarchy. The emergence of the compositional method of twelve tones was caused by necessity. Many experiments that had lasted for twelve years gave rise to a new method of musical composition that seemed appropriate to replace the structural differentiation that had previously been the subject of tonal harmony" (Schaeffer, 1952). Indeed, A. Schoenberg's new musical language and its organization due to the liberation from the strong enough influence of the neo-romantic tradition ( $R$. Wagner, G. Mahler, J. Brahms, J. Strauss, A. Dvorak, etc.) can be considered as a natural result of the musical ideological evolution, which reflected a significant qualitative breakthrough in the field of composition technique.

A similar parallel can be drawn with electronic music, which at the time of its emergence was not actually considered music. However, there were other points of view that exaggerated its significance, considering it to be a turning point in the history of musical development, the music of the future, which opens a new stage in musical history. Thus, back in 1954, Herbert Aymert, as one of the creators of this type of music, wrote: "Electronic music begins where the instrumental music ends" (Cahill, 1951). Talking about the complications associated with the perception of electronic music, it was noted that "electronic sounds should be listened to, rejecting any associations, not drawing parallels with all sorts of memories, without taking into account the accompanying thoughts about familiar music" (Winckei, 1963). It should be noted that today the above-mentioned polar views on electronic music have lost their relevance. In contrast, the connection between electronic music and postWebernian serialism and pointillism, as well as its affinity with timbre music, which dates back to impressionism, is becoming increasingly apparent.

H. Aymert considered electronic music to be the center of all musical aspirations, and something exceptional. From our point of view, $\mathrm{H}$. Aymert's opinion is a reflection of the situation that developed in the art of music in the 1960s, and is explained by the success of musical technology of that time, and in particular electronic means.

In any music, you can trace various types of connections with certain established traditions, because the emergence of anything new requires a proper basis. Thus, the emergence and gradual preservation of changes that occur in the musical thinking of the composer and reflected in his technique is a prerequisite for changes in historical development, which form new musical laws.

Experience has shown that musical perception cannot be completely devoid of the usual basis. Thus, thanks to it, the listener in the musical material has the opportunity to distinguish the general principles of composition, harmonic texture, timbre, rhythmic pulsation etc.

Accordingly, it would be a mistake to think that modern music should be perceived and created exclusively linearly, without taking into account other parameters and elements, even if they are pushed to the background. Thus, we question the aspirations and ideas of orthodox dodecaphonists, pointillists and others. A turning point in the history of musical art, which was the beginning of all further musical development, was the erosion of the dominance of major and minor scales at the beginning of the last century. This artistic innovation was most clearly manifested in such works as the ballet "The Rite of Spring" by I. Stravinsky and the melodramatic cycle "Pierrot in the Moonlight" by A. Schoenberg. Quite demonstrative are program slogans of that 
time, in which the main emphasis was placed on the denial of the idealization of the bourgeoisie and false romantic pathos, sentimentality. The truthfulness of art, expressive and realistic expression of real human feelings of the new era, which should be expressed by unusual, even somewhat crude means of expression, which can truly reflect the accelerated pace of life with its internal contradictions, began to come to the foreground. The further development of musical thinking was greatly influenced by rapidly changing social conditions, such as economic crises, world wars, rapid scientific and technological development, the emergence of gramophone, tape recorder, sound recording, electric lamp, unprecedented pace of life in big cities, the influence of jazz and oriental cultures etc. All this has led to the removal of creative methods not only of individual composers, but also of entire schools of composers.

Thus, certain directions of expressionism appeared which were represented by such composers as A. Schoenberg, A. Berg and O. Scriabin. The neoclassical style was presented by I. Stravinsky, after the composer wrote the fundamental works of the so-called Russian period: "Svadebka", "Petrushka", "The Rite of Spring". For such Hungarian composers as Z. Kodai and B. Bartok, the source of inspiration was novelty, natural simplicity and some unusualness of the folk music they used. In his turn, following M. Reger, P. Hindemith came to the neo-baroque.

The school of composers "Les Six" was founded in France, among whose representatives were D. Milhaud and A. Honegger. It tended to nonromantic, unconstructive music, which would be characterized by simplicity and mundanity. O. Messiaen, being a representative of another French school of composers called "Young France" ("JeuneFrance"), under the influence of mysticism tried to create compositions that would evoke the same feelings as church stained glass.

Czech composer A. Hába was one of the first composers to engage in 1/4-tone, 1/3-tone, $1 / 6$-tone and 1/12-tone (microchromatic) composition. To extract these microintervals he invented a piano with three keyboards.

Along with this, neo-romantic art, enriched with impressionism, gradually began to recede into the background, with such representatives as V. Novak, I. Suk and others. At the same time, Soviet realistic music began to assert itself in the former USSR, with Miaskovskyi, S. Prokofiev and D. Shostakovich as prominent representatives. Futuristic experiments are becoming increasingly popular. Thus, in 1914 Italian composer L. Russolo wrote "Four Pieces for 19 noise instruments". This work was a proof that "much more enjoyment can be obtained from the perfect combination of tram noise, cars, piston engines and noisy crowd than to listen to "Pastoral" or "Heroic" once again....." (Hiller, 1962).

Conclusions. Thus, the historical evolution of musical instruments is deeply connected with the creative processes that take place in the field of composition, acting skills, musicology and education. This led to the search and improvement of musical language, enrichment of compositor's methods, techniques and means of texture of musical works and, as a consequence, born of the electronic instruments.

\section{References}

Boulez, P. (2004). Landmarks 1: selected articles. Moscow: Logos-Al'tera. [In Russian].

Zaripov, R. (1971). Cybernetics and Music. Moscow: Nauka. [In Russian].

Kiyanovska, L. (2005). Socio-cultural aspect of the development of electronic music in the 50-70's of the twentieth century. Muzychne mystetstvo i kultura. (Issue 6. Book 1, p. 114-124). [In Ukrainian].

Kogoutek, T. (1976). Composition technique in the music of the XX century. Moscow: Muzyka. [In Russian].

Xenakis, J. (2008). Formalized music: new formal principles of musical composition. St. Petersburg: St. Petersburg State Conservatory named after Nikolai Andreevich Rimsky-Korsakov. [In Russian].

Lazarev, S. (2011). Electronic music as a form of artistic creativity. Muzychno-teatralne mystetstvo, 1, 196199. [In Ukrainian].

Mole, A., Foucault, W., Kassler, M. (1975). Art and computers. Moscow: Mir. [In Russian].

Cahill, T. (1951). Electrical Music as a Medium of Expression. Electronics, 24, 12-32. [In English].

Hiller, L. (1962). Muzyczne zastosowanie elektronowych maszyn cyfrowych. Ruch muzyczny, 7, 5. [In Polish].

Schaeffer, P. (1952). A la Recherche d'une Musique Concrete. Paris: Editions du Seuil. [In French].

Winckei, F. (1963). Berliner Elektronik. Melos, 9, 2756. [In English].

Надійшла до редколегії 15.10.2020 